\title{
Prevention of P2 Receptor-Dependent Thrombocyte Activation by Pore-Forming Bacterial Toxins Improves Outcome in A Murine Model of Urosepsis
}

\author{
Mette G. Christensen ${ }^{1, \dagger}$, Nanna Johnsen ${ }^{1,+}$, Marianne Skals ${ }^{1}$, Aimi D. M. Hamilton ${ }^{1}$, \\ Peter Rubak ${ }^{2}$, Anne-Mette Hvas ${ }^{3}$ and Helle Praetorius ${ }^{1, *(D)}$ \\ 1 Department of Biomedicine, Aarhus University, 8000 Aarhus C, Denmark; mgch@biomed.au.dk (M.G.C.); \\ nanna-johnsen@biomed.au.dk (N.J.); msk@nmdpharma.com (M.S.); aiha@biomed.au.dk (A.D.M.H.) \\ 2 Clinic for Diagnostics, Aalborg University Hospital, 9000 Aalborg, Denmark; peterrubak@gmail.com \\ 3 Department of Clinical Biochemistry, Aarhus University Hospital, 8000 Aarhus C, Denmark; \\ annehvas@rm.dk \\ * Correspondence: hp@biomed.au.dk \\ + The authors marked with ${ }^{\dagger}$ share equal contribution.
}

Received: 15 May 2020; Accepted: 4 August 2020; Published: 6 August 2020

\begin{abstract}
Urosepsis is a potentially life-threatening, systemic reaction to uropathogenic bacteria entering the bloodstream of the host. One of the hallmarks of sepsis is early thrombocyte activation with a following fall in circulating thrombocytes as a result of intravascular aggregation and sequestering of thrombocytes in the major organs. Development of a thrombocytopenic state is associated with a poorer outcome of sepsis. Uropathogenic Escherichia coli frequently produce the pore-forming, virulence factor $\alpha$-haemolysin (HlyA), of which the biological effects are mediated by ATP release and subsequent activation of $\mathrm{P} 2$ receptors. Thus, we speculated that inhibition of thrombocyte $\mathrm{P}_{2} \mathrm{Y}_{1}$ and P2 $\mathrm{Y}_{12}$ receptors might ameliorate the septic response to HlyA-producing E. coli. The study combined in vitro measurements of toxin-induced thrombocyte activation assessed as increased membrane abundance of P-selectin, fibronectin and CD63 and data from in vivo murine model of sepsis-induced by HlyA-producing E. coli under infusion of $\mathrm{P}_{2} \mathrm{Y}_{1}$ and $\mathrm{P}_{2} \mathrm{Y}_{12}$ antagonists. Our data show that the $\mathrm{P} \mathrm{Y}_{1}$ receptor antagonist almost abolishes thrombocyte activation by pore-forming bacterial toxins.

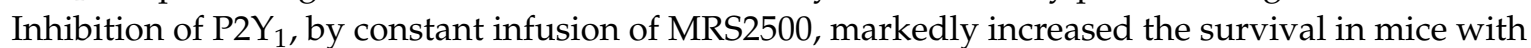
induced sepsis. Moreover, MRS2500 partially prevented the sepsis-induced depletion of circulating thrombocytes and dampened the sepsis-associated increase in proinflammatory cytokines. In contrast, $\mathrm{P} \mathrm{Y}_{12}$ receptor inhibition had only a marginal effect in vivo and in vitro. Taken together, inhibition of the $\mathrm{P}_{2} \mathrm{Y}_{1}$ receptor gives a subtle dampening of the thrombocyte activation and the cytokine response to bacteraemia, which may explain the improved survival observed by $\mathrm{P}_{2} \mathrm{Y}_{1}$ receptor antagonists.
\end{abstract}

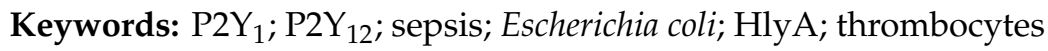

\section{Introduction}

Sepsis is a life-threatening condition with an overwhelming immune response to infection. Unfortunately, the number of patient admissions under the diagnosis sepsis is markedly increasing [1], frequently with the urinary tract as the primary infection site [2,3]. Urinary tract infections are regularly caused by Escherichia coli (for review, see [4]) in both the primary and secondary health sector. The E. coli that causes severe infections, such as pyelonephritis, are known to vary serotypically from E. coli in the intestinal microbiome [5-7] and produce a variety of virulence factors [5-9]. Of those, $\alpha$-haemolysin (HlyA) is the most frequent in clinical isolates [10] and is thus, associated with the ability to create and sustain severe infection. Our previous data support that HlyA is largely responsible for the 
septic symptoms observed in response to bacteraemia with uropathogenic E. coli [11]. Interestingly, the biological effects of HlyA are intimately associated with extracellular adenosine triphosphate (ATP) signalling [12-16]. This is a consequence of ATP being released in a non-lytic fashion directly through the pore created by HlyA [17] and subsequent activation of P2 receptors [12-16,18]. Since ATP is a renowned damage-associated molecular pattern (DAMP) molecule [19], it is thus an aggressive activator of immune cells and a prime candidate for promoting the cytokine rush during septic shock. In this context, it is interesting that the phenomenon of ATP-mediated amplification of virulence is not unique for HlyA, but is a feature for several other bacterial pore-forming toxins [20-24] and membrane attack complex from the complement system [25]. This essentially implies that P2 receptor signalling is likely to be a more general issue in sepsis.

Sepsis and septic shock are associated with a very early reduction in circulating thrombocytes, and thrombocytopenia is generally associated with a poorer outcome in sepsis [26,27]. This does not immediately imply that a low level of circulating thrombocytes, per se, is responsible for the poorer outcome of sepsis. However, the sepsis-induced reduction in circulating thrombocytes reflects both organ accumulation but is also a consequence of microthrombus formation [28]. This obstruction of the microcirculation is responsible for the reduced tissue oxygenation and multiorgan failure seen during severe sepsis (for overview, see [29]). The drop in circulating thrombocytes is easily confirmed in our sepsis model, a process markedly accelerated by the presence of HlyA [11]. Thus, it is tempting to speculate that HlyA-induced ATP release and subsequent intravascular degradation to adenosine diphosphate (ADP) would contribute to escalate the thrombocyte activation and thereby increase the mortality in E. coli-induced sepsis.

Thrombocytes express three P2 receptor subtypes: $\mathrm{P} 2 \mathrm{X}_{1}, \mathrm{P}_{2} \mathrm{Y}_{1}$ and $\mathrm{P} 2 \mathrm{Y}_{12}$ (for review, see [30]). ATP is an agonist for both the $\mathrm{P} 2 \mathrm{X}_{1}$ and $\mathrm{P} 2 \mathrm{Y}_{1}$ receptors [31,32], whereas $\mathrm{P}_{2} \mathrm{Y}_{12}$ and $\mathrm{P} 2 \mathrm{Y}_{1}$ receptors are responsible for the renowned ADP-mediated thrombocyte activation [33-35]. Thus, it would be logical to target either of the thrombocyte P2 receptors to prevent sepsis-induced thrombocyte activation. Interestingly, mice lacking the $\mathrm{P}_{2} \mathrm{X}_{1}$ receptor are protected against the sepsis-induced cytokine rush [36]. However, specific inhibition of $\mathrm{P} 2 \mathrm{X}_{1}$ receptors causes an acute reduction of circulating thrombocytes in itself and, thus, subsequently decreases the overall survival of urosepsis [37]. Therefore, the P2X receptor is not immediately a promising target to reduce thrombocyte activation during sepsis. Here, we hypothesise that interference with either $\mathrm{P}_{2} \mathrm{Y}_{1}$ or $\mathrm{P}_{2} \mathrm{Y}_{12}$ may dampen the thrombocyte activation and improve the survival in a murine model of urosepsis.

The data demonstrate that thrombocyte activation in vitro with pore-forming toxins requires P2 receptor activation and is essentially abolished by inhibition of $\mathrm{P}_{2} \mathrm{Y}_{1}$, whereas inhibition of $\mathrm{P}_{2} \mathrm{Y}_{12}$ only moderately reduced the thrombocyte activation. Moreover, constant infusion of a P2 $\mathrm{Y}_{1}$ receptor antagonist in a murine model of urosepsis markedly reduced the overall mortality. This finding is associated with a less pronounced reduction in circulating thrombocytes in response to sepsis and a reduced proinflammatory response to a given load of circulating E. coli. Interestingly, infusion of a $\mathrm{P} \mathrm{Y}_{12}$ receptor antagonist, cangrelor, showed a tendency towards improving survival, even though this was not statistically significant. Similar to inhibiting the $\mathrm{P} 2 \mathrm{X}_{1}$ receptor [37], cangrelor reduced the plasma levels of proinflammatory cytokines. Thus, we can conclude that inhibition of P2Y 1 receptors improves the survival of sepsis induced by HlyA-producing E. coli possibly by dampening the thrombocyte and cytokine response.

\section{Results}

Pore-forming bacterial toxins are intimately associated with release of intracellular ATP to the extracellular compartment. The biological action of ATP is associated with P2X or P2Y receptor activation on various cell types, such as erythrocytes, monocytes and renal epithelial cells $[12,13,16,20,22]$. The pore-forming bacterial toxin, $\alpha$-toxin from $S$. aureus has previously been shown to be able to initiate thrombocyte aggregation [38]. Therefore, we tested whether thrombocyte $\mathrm{P}_{2} \mathrm{Y}_{1}$ and $\mathrm{P} 2 \mathrm{Y}_{12}$ receptors are involved in the thrombocyte activation triggered by bacterial pore-formers. To test this, thrombocyte 
activation was measured by flow cytometry as a combined increase in fibronectin, CD63 and P-selectin positive thrombocytes as previously described [39]. Figure 1A shows the level of P-selectin expression on thrombocytes in healthy volunteers in relation to the maximal thrombocyte activation achieved with $140 \mu \mathrm{M}$ ADP or $371 \mu \mathrm{M}$ thrombocyte activating peptide (TRAP) as positive controls. With this technique, we could easily verify that $\alpha$-toxin from Staphylococcus aureus markedly activated human thrombocytes both in whole blood (Figure 1A) and in platelet enriched plasma (data not shown). Our data demonstrate that thrombocyte activation was not exclusive to $\alpha$-toxin but could be recapitulated with leukotoxin $\mathrm{A}$ (LtxA) from Aggregatibacter actinomycetemcomitans, which similarly to HlyA belongs to the repeat-in-toxin (RTX) family of bacterial pore-formers (Figure 1A). In high concentrations, both toxins activated the thrombocytes to a level similar to the positive controls (data not shown). However, the concentration of pore-forming toxins was adjusted to gain approximately $25 \%$ thrombocyte activation to allow detection of both inhibitory and potentiating effects (Figure 1A). The in vitro studies could unfortunately not be performed by HlyA itself. HlyA requires $\mathrm{Ca}^{2+}$ to insert into biological membranes, and, because addition of $\mathrm{Ca}^{2+}$ alone caused a sizable and very variable thrombocyte activation, it was not possible to quantitate the HlyA response in a reliable manner. However, our previous studies have demonstrated that, in terms of ATP-dependent amplification of the biological effect of HlyA, $\alpha$-toxin and LtxA are quite similar $[12,17,18,20,22]$. Figure $1 \mathrm{~B}$ verifies that ADP-dependent thrombocyte activation indeed is inhibited by selective antagonists towards the two thrombocyte P2Y receptors, P2Y 1 (MRS2500) and P2Y 12 (PSB0739), used in the study.

Consistent with our previous studies on erythrocytes, the biological effects of $\alpha$-toxin and LtxA was markedly inhibited by P2 receptor inhibition on thrombocytes [20,22]. Figure 1C shows that MRS2500 $(9 \mu \mathrm{M})$ reduced the thrombocyte activation induced by LtxA considerably (around $80 \%$ ) regardless of whether the readout was fibronectin, CD63 or P-selectin. PSB0739 $(18 \mu \mathrm{M})$ showed the same tendency, with $\sim 60 \%$ inhibition of the LtxA-induced thrombocyte activation, but the results were not statistically significantly different from samples exposed to LtxA alone (Figure 1C). Combining the antagonists only had a marginally additional effect to MRS2500 alone. Similar results were found with $\alpha$-toxin, only here the effect of PSB0739 was even less pronounced ( 55\% inhibition, Figure 1D). Thus, we can confirm that the biological effect on thrombocytes of two pore-forming toxins largely is caused by secondary purinergic signalling. Since the data were obtained from whole blood samples, it is reasonable to assume that the ADP activating the thrombocytes originated from ATP released from erythrocytes in response to the pore-forming toxins [20,22]. Therefore, we tested whether the toxins could activate the thrombocytes directly and whether this effect was P2Y receptor-dependent. In platelet enriched plasma (PRP), the pore-forming toxins $\alpha$-toxin and LtxA still activated the thrombocytes. Similar to what was shown in whole blood, the P2Y receptor antagonists still lowered the thrombocyte activation in response to the pore-forming toxins (20-40\% reduction, Figure 1E). However, the overall effect was less pronounced compared to whole blood samples. This potentially suggests that the effect of pore formation was less amplified by ATP release and subsequent P2 receptor activation when thrombocytes are not surrounded by other blood cells. This supports the notion that thrombocyte activation by the pore-forming toxins in whole blood is likely to be amplified by ATP released from erythrocytes or other of the formed blood components. 

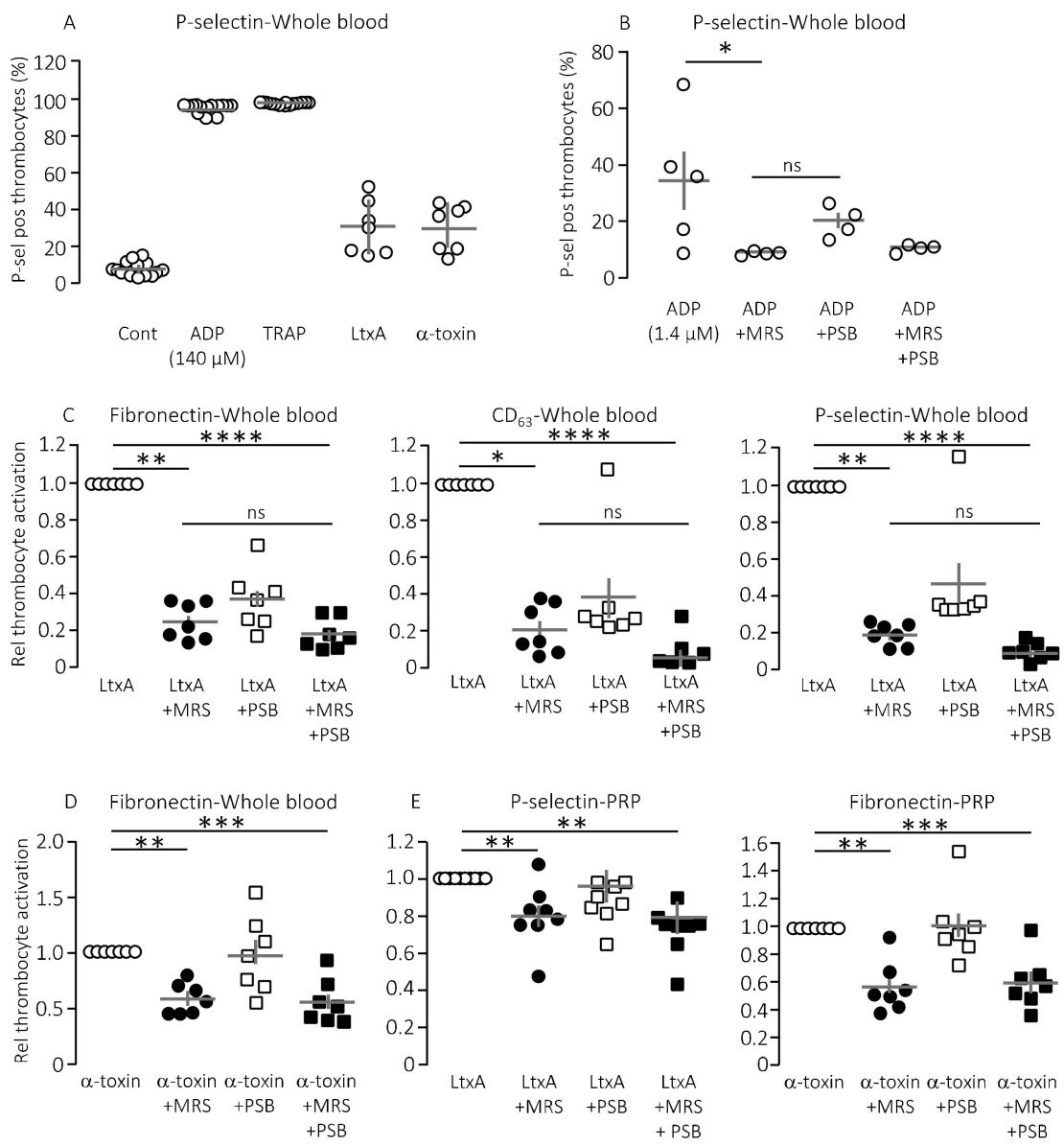

Figure 1. The effect of $\mathrm{P} 2 \mathrm{Y}$ receptor blockade on the thrombocyte activation induced by pore-forming toxins in vitro. Thrombocyte activation is measured as the P-selectin, fibronectin and CD63 positive cells as a percentage of the total number of thrombocytes. (A) The pore-forming toxin $\alpha$-toxin $(n=7)$ and leukotoxin A (LtxA, $30 \mu \mathrm{g} \mathrm{mL}^{-1}, n=7$ ) readily activates thrombocytes here shown as the relative number of P-selectin positive thrombocytes. Activation of thrombocytes with adenosine diphosphate (ADP, $140 \mu \mathrm{M}$, $n=14$ ) and thrombocyte activating peptide (TRAP, $371 \mu \mathrm{M}, n=14$ ) was used as positive controls and a HEPES-buffered solution was used as negative control (Cont). The addition of pore-forming toxin was adjusted to give a thrombocyte activation of approximately $25 \%$. (B) The effect of $\mathrm{P} 2 \mathrm{Y}_{1}$ and $\mathrm{P} 2 \mathrm{Y}_{12}$ receptor inhibition on the ADP-induced thrombocyte activation. MRS2500 (MRS) was used in a concentration of $9 \mu \mathrm{M}$ and PSB0739 (PSB) $18 \mu \mathrm{M}$. (C) The effect of MRS2500 $9 \mu \mathrm{M}(n=7)$ and PSB0739 $18 \mu \mathrm{M}(n=7)$ on the thrombocyte activation induced by LtxA in whole blood measured as fibronectin, CD63 and P-selectin positive thrombocytes. For the combined effect of MRS2500 and PSB0739 $n=7$. (D) The effect of MRS2500 $9 \mu \mathrm{M}(n=7)$ and PSB0739 $18 \mu \mathrm{M}(n=7)$ on $\alpha$-toxin-induced thrombocyte activation in whole blood. For the combined effect of MRS2500 and PSB0739( $n=7)$. (E) The effect of MRS2500 $9 \mu \mathrm{M}(n=8)$ and PSB0739 $18 \mu \mathrm{M}(n=8)$ on LtxA-induced or $\alpha$-toxin-induced thrombocyte activation in platelet enriched plasma (PRP). For the combined effect of MRS2500 and PSB0739 $n=8$. All data are given as single observations and mean \pm S.E.M. ${ }^{*} p<0.05,{ }^{* *} p<0.01,{ }^{* * *} p<0.001$ and ${ }^{* * * *} p<0.0001$.

The question is whether this finding has any bearing in vivo. To test this, we used a murine sepsis model with direct injection into the tail vein of $E$. coli producing the pore-forming toxin $\alpha$-haemolysin (HlyA) [11,36]. Our previous studies have demonstrated that HlyA secreted from uropathogenic E. coli constitute a marked virulence factor solely responsible for the septic response during bacteraemia [11]. We demonstrated that the mice only developed septic symptoms when the HlyA operon was expressed in an E. coli strain (K12) without any other important virulence factors. Figure 2A shows that constant infusion with the $\mathrm{P}_{2} \mathrm{Y}_{1}$ receptor antagonist MRS2500 $(25.9 \mu \mathrm{g} / \mathrm{h}) \mathrm{compared}$ to saline infusion increased 
the survival of mice exposed to the exact same HlyA-producing E. coli strain $(p=0.048)$. We confirm that the induction of sepsis is associated with a substantial drop in circulating thrombocytes (Figure 2B). In this controlled sepsis model, the reduction in circulating thrombocytes is likely to reflect the degree of intravascular thrombocyte activation [40,41]. Interestingly, the mice infused with MRS2500 did not exhibit the reduction in thrombocytes typically observed in response to sepsis with uropathogenic E. coli in this mouse model (Figure 2B) [11,36]. In mice exposed to saline infusion, the number of thrombocytes drops to $56 \%$ after 2.5 -h exposure to $30 \times 10^{6}$ E. coli $(p=0.005)$. However, in mice infused with MRS2500, this reduction was no longer statistically significant (22\% reduction after $2.5 \mathrm{~h}, p=0.600$, Figure 2B). Of note, the mice infused with MRS2500 developed haemoglobinuria earlier (after $168 \mathrm{~min}$ ) than mice exposed to saline infusion (after $253 \mathrm{~min}, p=0.070$, Figure 2C) despite having the same degree of intravascular haemolysis ( $p=0.340$, Figure 2D) and activation of intravascular coagulation (Figure 2E). Thus, ${\mathrm{P} 2 \mathrm{Y}_{1}}_{1}$ receptor inhibition seemingly ameliorates some of the septic symptoms in mice directly without affecting the severity of the infection.
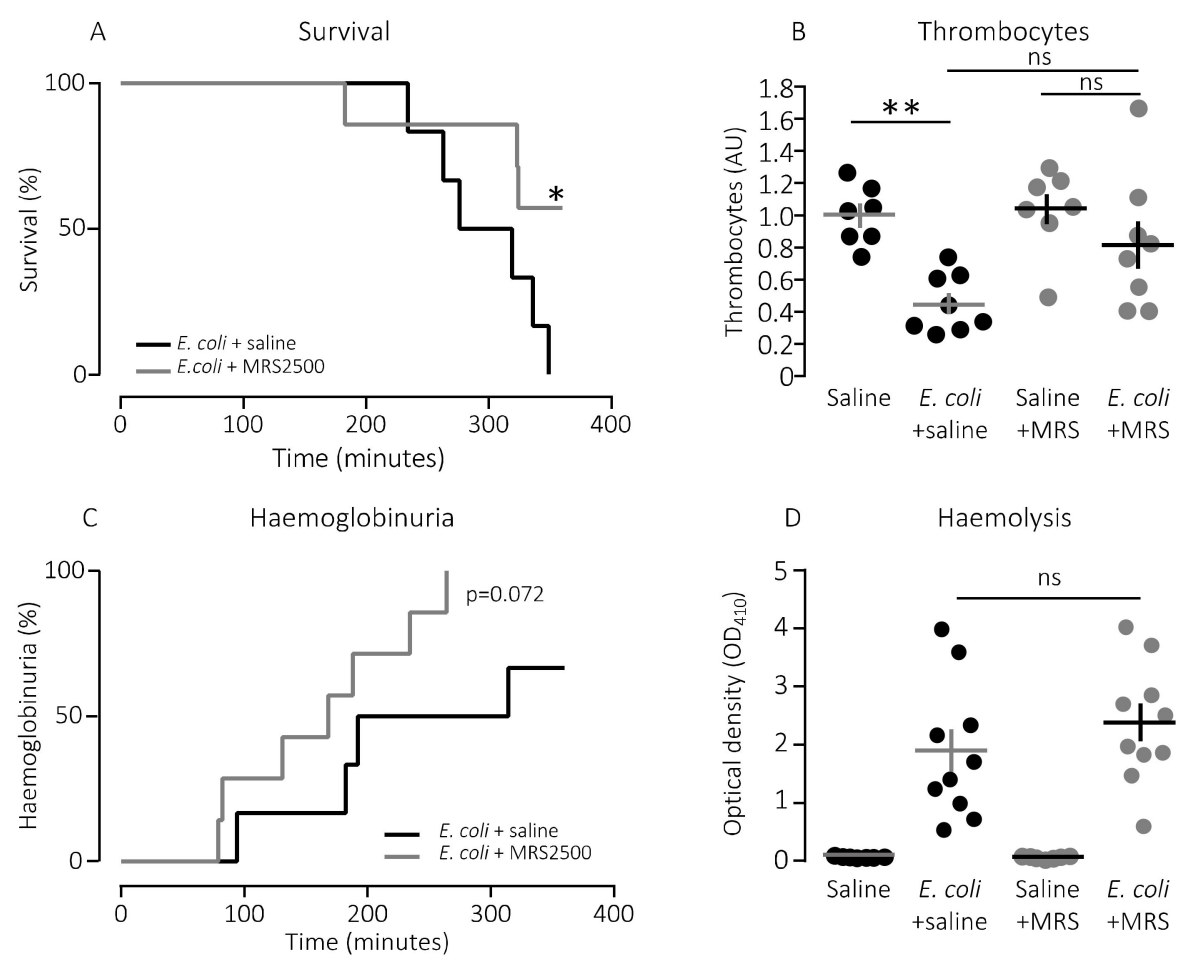

E Thrombin-antithrombin complex

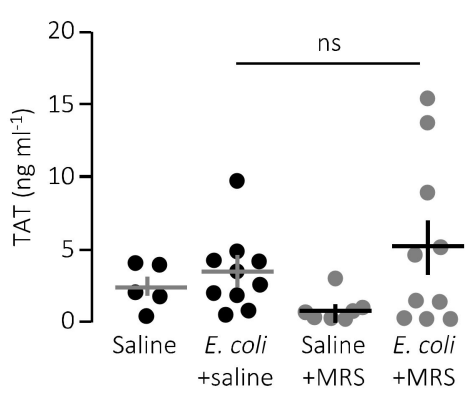

Figure 2. $\mathrm{P} 2 \mathrm{Y}_{1}$ receptor antagonist MRS2500 (MRS) increase survival of mice exposed to sepsis with E. coli. 
(A) Mice with bacteraemia receiving continuous infusion of either saline $(n=6)$ or the P2Y receptor antagonist MRS2500 $(25.9 \mu \mathrm{g} / \mathrm{h}, n=7)$ for up to $6 \mathrm{~h}$. The mice subjected to bacteraemia received $30 \times 10^{6}$ E. coli (WAM1824) iv. Data are shown as Kaplan-Meyer plot, ${ }^{*}$ indicates $p<0.05$. (B) The relative number of thrombocytes $2.5 \mathrm{~h}$ after injection of $30 \times 10^{6} \mathrm{E}$. coli iv (saline $n=7, \mathrm{E}$. coli + saline $n=8$, saline + MRS2500 $(25.9 \mu \mathrm{g} / \mathrm{h}) n=7$, E. coli + MRS2500 $(25.9 \mu \mathrm{g} / \mathrm{h}) n=8)$. (C) Development of haemoglobinuria in mice exposed to $30 \times 10^{6} \mathrm{E}$. coli for up to $6 \mathrm{~h}$ infused with either saline $(n=6)$ or the $\mathrm{P}_{2} \mathrm{Y}_{1}$ receptor antagonist MRS2500 $(25.9 \mu \mathrm{g} / \mathrm{h}, n=7)$. (D) Degree of intravascular haemolysis after exposure to $30 \times 10^{6} \mathrm{E}$. coli for $2.5 \mathrm{~h}$ (All groups $n=10$ ). (E) The intravascular formation of thrombin-antithrombin complexes (saline $n=5$, E. coli + saline $n=10$, saline + MRS2500 $(25.9 \mu \mathrm{g} / \mathrm{h})$ $n=7$, E. coli + MRS2500 $(25.9 \mu \mathrm{g} / \mathrm{h}) n=10)$. The data are given as single observations and mean \pm S.E.M, ${ }^{*} p<0.05$ and ${ }^{* *} p<0.01$.

We speculated that lower mortality in mice exposed to MRS2500 might result from a dampening of the proinflammatory cytokine response since high levels of proinflammatory cytokines are associated with a negative outcome of sepsis [42]. However, to our surprise, MRS2500 only had a minor effect on the cytokine response to infection with HlyA-producing E. coli per se. Figure 3 demonstrates the well-documented increase in plasma levels of the proinflammatory cytokines tumour necrosis factor factor $\alpha$ (TNF- $\alpha$ ), interleukin-1 $\beta$ (IL-1 $\beta)$, IL-6 and the mouse ligand for the IL-8 receptor, keratinocyte chemoattractant (KC) in response to iv-injection of the HlyA-producing E. coli [11,36]. The response was seemingly similar in mice exposed to MRS2500 and saline infusion, except for KC where the plasma-levels were statistically significantly higher in mice infused with MRS2500 (Figure 3B, $p=0.0005$ ). However, when the cytokine response was evaluated relative to the measured intravascular bacterial load, the proinflammatory cytokines tended to be lower at a given stage of infection in mice exposed to MRS2500 compared to mice exposed to saline (Figure 4B-E). This was the case for all the proinflammatory cytokines (IL-6, $p=0.0002$; IL-1 $\beta, p=0.005$; TNF- $\alpha, p=0.033$ ) except KC $(p=0.472$ ).
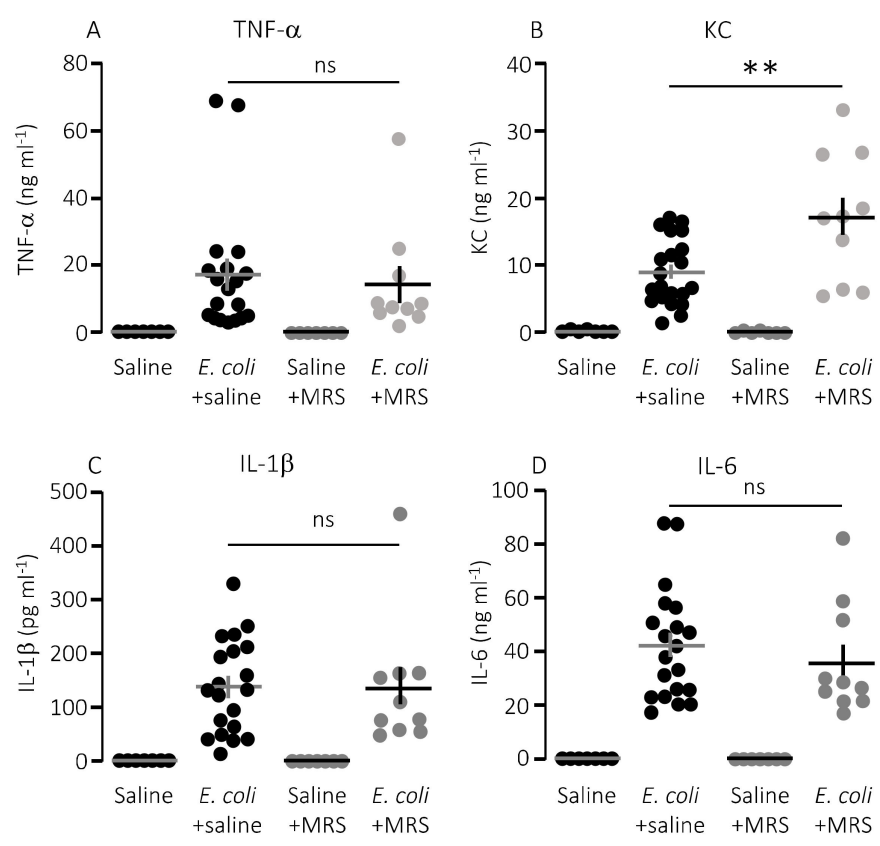

Figure 3. $P 2 Y_{1}$ receptor antagonist MRS2500 (MRS) increase the proinflammatory cytokine keratinocyte chemoattractant in mice exposed to sepsis with E. coli. The level of the following proinflammatory cytokines were measured in plasma from mice exposed to saline or MRS2500 infusion $(25.9 \mu \mathrm{g} / \mathrm{h})$ in the absence or presence of $30 \times 10^{6}$ E. coli iv: (A) TNF- $\alpha$; (B) keratinocyte chemoattractant (KC); (C) IL-1 $\beta$; and (D) IL-6. The data are given as single observations and mean \pm S.E.M (saline $n=7$, E. coli + saline $n=20$, Saline + MRS2500 $n=7$, E. coli + MRS2500 $(25.9 \mu \mathrm{g} / \mathrm{h}) n=10),{ }^{* *} p<0.01$. 

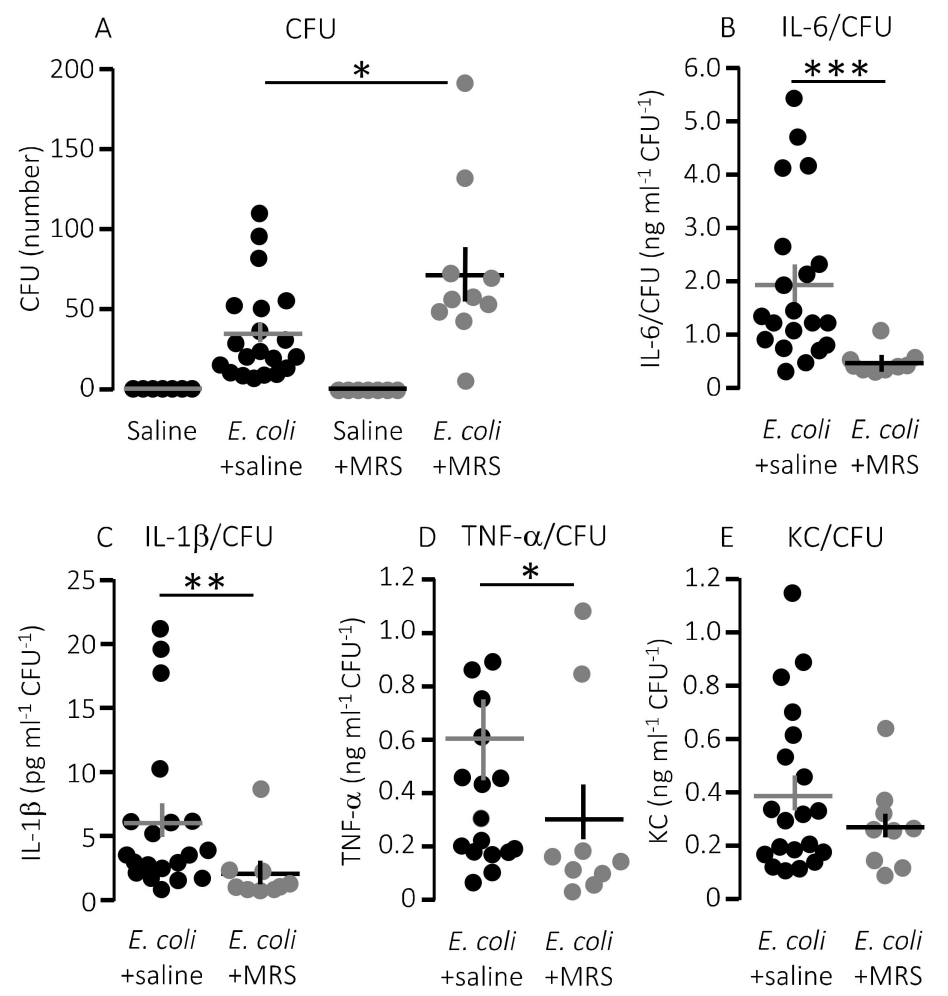

Figure 4. The cytokine response relative to the degree of infection inflicted by injection of HlyA-producing E. coli in the absence or presence of infusion of $\mathrm{P}_{2} \mathrm{Y}_{1}$ receptor antagonist. (A) The number of colony forming units (CFU) from streaking out $5 \mu \mathrm{L}$ whole blood (diluted as described in methods) of mice infused with either control solution or MRS2500 $(25.9 \mu \mathrm{g} / \mathrm{h})$ in the presence or absence of sepsis with HlyA-producing E. coli. (B-E) The cytokine [(B) IL-6; (C) IL-1 $\beta$; (D) TNF- $\alpha$; and (E) $\mathrm{KC}$ ] response relative to the infection status represented by the number of colony-forming units. The data are given as single observations and mean \pm S.E.M (saline $n=7$, E. coli + saline $n=20$, saline + MRS2500 $n=7$, E. coli + MRS2500 $(25.9 \mu \mathrm{g} / \mathrm{h}) n=10),{ }^{*} p<0.05,{ }^{* *} p<0.01,{ }^{* * *} p<0.001$.

Notably, the improved survival of mice infused with MRS2500 did not result from a more effective clearance of bacteria from the blood. MRS2500 infusion actually resulted in a statistically significantly higher number of circulating bacteria in the blood after $2.5 \mathrm{~h}$ compared to mice exposed to saline infusion (Figure $4 \mathrm{~A}, p=0.03$ ). Thus, constant infusion of the $\mathrm{P}_{2} \mathrm{Y}_{1}$ receptor antagonist increases the survival of mice with acute urosepsis despite a slightly higher level of circulating bacteria.

In a clinical context, the $\mathrm{P}_{2} \mathrm{Y}_{12}$ receptor is a more established target for pharmacologic inhibition of thrombocyte activation. However, our in vitro data show a larger effect of $\mathrm{P}_{2} \mathrm{Y}_{1}$ receptor inhibition on thrombocyte activation compared to a $\mathrm{P}_{2} \mathrm{Y}_{12}$ receptor antagonist after exposure to pore-forming bacterial toxins. To investigate whether this pattern was also reflected in the in vivo data, we infused the $\mathrm{P}_{2} \mathrm{Y}_{12}$ receptor antagonist, cangrelor, in mice exposed to HlyA-producing E. coli. Figure 5A shows that cangrelor at an infusion rate of $8.6 \mu \mathrm{g} / \mathrm{h}$ (low dose) had a tendency towards improved survival, although it did not reach statistical significance $(p=0.070)$. Therefore, we increased the infusion rate to $86.6 \mu \mathrm{g} / \mathrm{h}$, which counteracted the potential slight beneficial effect seen at the lower dose (Figure 5A). Similarly, cangrelor at $8.6 \mu \mathrm{g} / \mathrm{h}$ was not able to prevent the bacteria-induced reduction in circulating thrombocytes ( $\sim 50 \%$ reduction in both groups, Figure $5 \mathrm{~B})$, and there was no observable difference in either the intravascular haemolysis ( $p=0.800$, Figure 5D) or the onset of haemoglobinuria (142 min (saline) and $93 \mathrm{~min}$ (cangrelor), $p=0.700$, Figure 5C). Neither did we detect any difference in the bacteria-induced activation of intravascular coagulation measured as formed thrombin-antithrombin (TAT) complexes in the absence or presence of cangrelor $(8.6 \mu \mathrm{g} / \mathrm{h}$, Figure $5 \mathrm{E})$. However, the trend that inhibiting thrombocyte $\mathrm{P} 2$ receptors diminished the proinflammatory cytokine response was also 
observed when infusing cangrelor. Figure 6 shows that the plasma levels of KC were significantly lower (Figure $6 \mathrm{~B}, p=0.017)$ in septic mice infused with cangrelor $(8.6 \mu \mathrm{g} / \mathrm{h})$ compared to those infused with saline. The same pattern was seemingly true for IL-1 $\beta$ (Figure $6 \mathrm{C}, p=0.065$ ) and IL-6 (Figure 6D, $p=0.066$ ), where the cangrelor infused plasma levels were on the rim of being statistically significantly lower than the saline controls. In contrast to $\mathrm{P}_{2} \mathrm{Y}_{1}$-antagonist infusion, we did not find the number of circulating bacteria after $2.5 \mathrm{~h}$ to be different with or without cangrelor $(p=0.2$, Figure $7 \mathrm{~A})$. When the proinflammatory cytokines were expressed relative to the number of circulating bacteria, the cytokine levels were no longer statistically significantly different between the two groups (Figure 7B-E). These data suggest that inhibition of $\mathrm{P}_{2} \mathrm{Y}_{12}$ receptors, at best, gives a marginal effect on the outcome of sepsis.
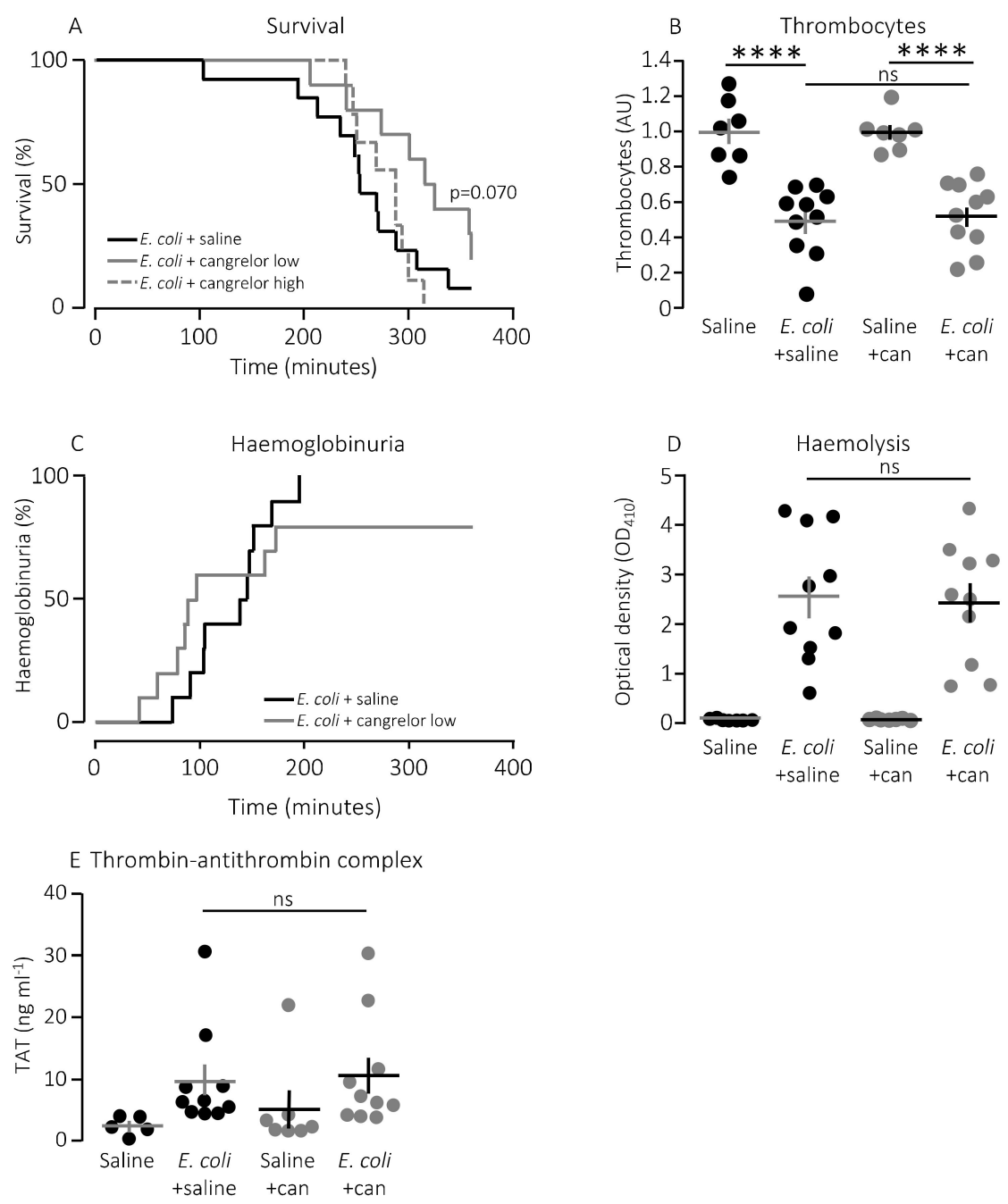

Figure 5. The effect of $\mathrm{P}_{2} \mathrm{Y}_{12}$ receptor antagonist cangrelor (can) in mice with sepsis. (A) Mice with bacteraemia receiving continuous infusion of either saline $(n=13)$ or cangrelor $(8.6 \mu \mathrm{g} / \mathrm{h}, n=10 \mathrm{or} 86.0 \mu \mathrm{g} / \mathrm{h}$, $n=9$ ) for up to $6 \mathrm{~h}$. The mice subjected to bacteraemia received $30 \times 10^{6} \mathrm{E}$. coli (WAM1824) iv. Data are shown as Kaplan-Meyer plot. (B) The relative number of thrombocytes $2.5 \mathrm{~h}$ after injection of $30 \times 10^{6}$ E. coli iv (saline $n=7$, E. coli + saline $n=10$, saline + cangrelor $(8.6 \mu \mathrm{g} / \mathrm{h}) n=7$, E. coli + cangrelor $(8.6 \mu \mathrm{g} / \mathrm{h})$ $n=10)\left(\right.$ C) development of haematuria in mice exposed to $30 \times 10^{6}$ E. coli for up to $6 \mathrm{~h}$ and infused with either saline $(n=13)$ or the $\mathrm{P}_{2} \mathrm{Y}_{12}$ receptor antagonist cangrelor $(8.6 \mu \mathrm{g} / \mathrm{h}, n=10)$ for op to $6 \mathrm{~h}$. (D) Degree of intravascular haemolysis after exposure to $30 \times 10^{6} \mathrm{E}$. coli for $2.5 \mathrm{~h}$ (saline $n=7$, E. coli + saline $n=10$, saline + cangrelor $(8.6 \mu \mathrm{g} / \mathrm{h}) n=7$, . coli + cangrelor $(8.6 \mu \mathrm{g} / \mathrm{h}) n=10)$. (E) The intravascular formation of thrombin-antithrombin complexes (saline $n=7, E$. coli + saline $n=10$, saline + cangrelor $(8.6 \mu \mathrm{g} / \mathrm{h})$ $n=7$, E. coli + cangrelor $(8.6 \mu \mathrm{g} / \mathrm{h}) n=10)$. The data are given as single observations and mean \pm S.E.M, $* * * * p<0.0001$. 

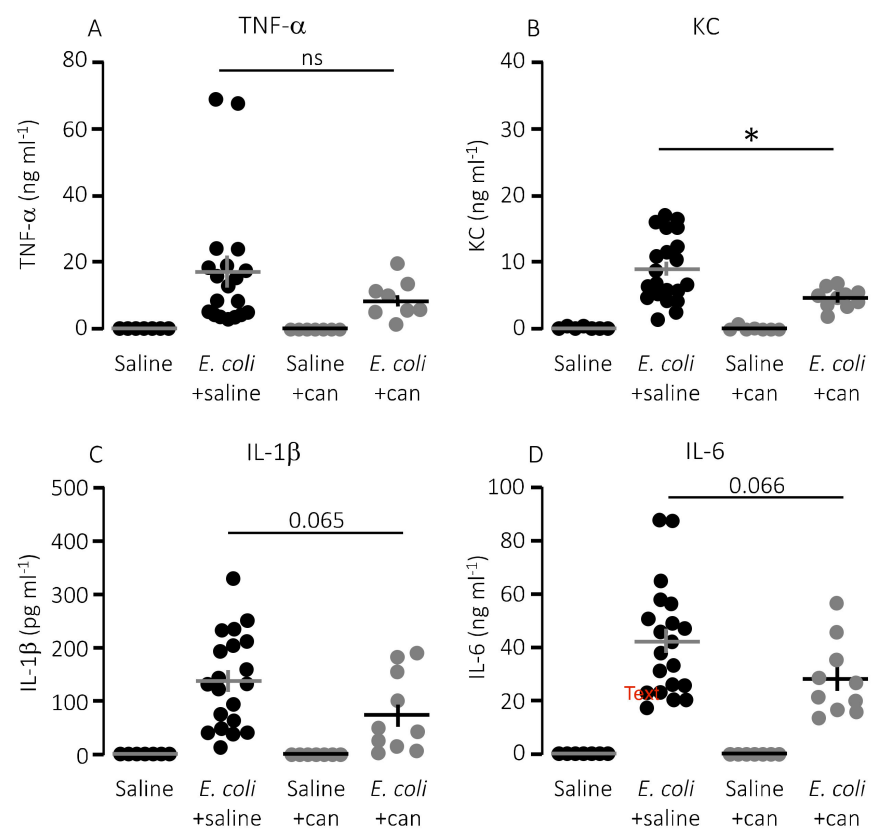

Figure 6. $\mathrm{P}_{2} \mathrm{Y}_{12}$ receptor antagonist cangrelor (can) does significantly reduce keratinocyte chemoattractant $(\mathrm{KC})$ in mice exposed to $E$. coli iv. The level of the following proinflammatory cytokines were measured in plasma from mice exposed to saline or cangrelor infusion $(8.6 \mu \mathrm{g} / \mathrm{h})$ in the absence or presence of $30 \times 10^{6}$ E. coli iv: (A) TNF- $\alpha$; (B) KC; (C) IL-1 $\beta$; and (D) IL-6. The data are given as single observations and mean \pm S.E.M (saline $n=7, E$. coli + saline $n=20$, saline + cangrelor $n=7$, E. coli + cangrelor $(8.6 \mu \mathrm{g} / \mathrm{h}) n=10)$, * $p<0.05$.
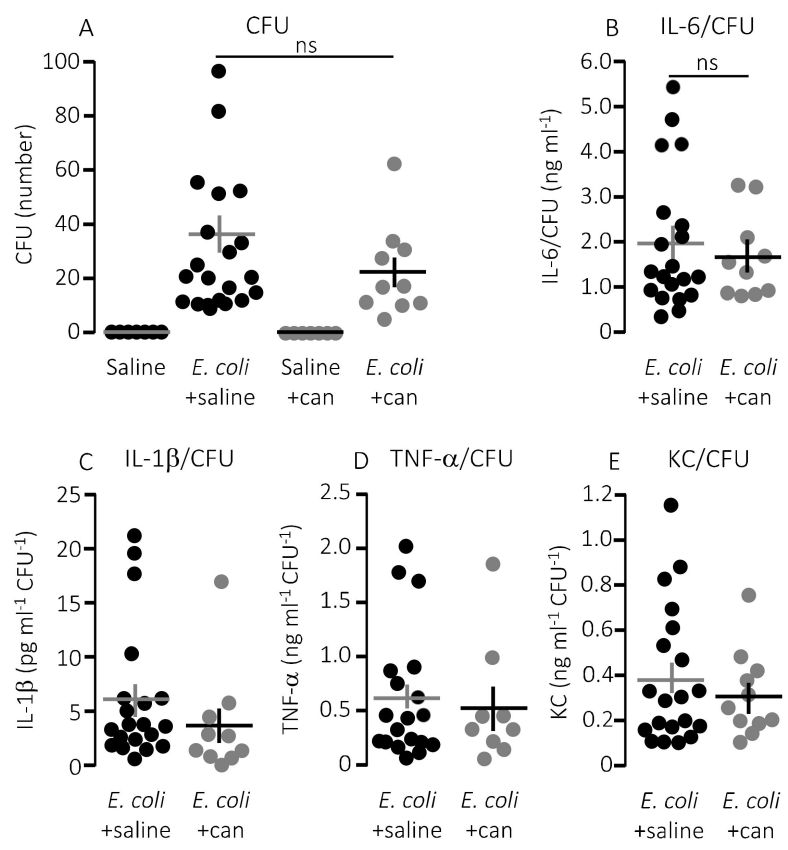

Figure 7. The cytokine-response relative to the degree of infection inflicted by injection of HlyA-producing E. coli in the absence or presence of infusion of $\mathrm{P}_{2} \mathrm{Y}_{12}$ receptor antagonist. (A) The number of colony forming units (CFU) from streaking out $5 \mu \mathrm{L}$ whole blood of mice infused with control solution or cangrelor $(8.6 \mu \mathrm{g} / \mathrm{h})$ either after exposure to HlyA-producing E. coli or saline solution. (B-E) The cytokine [(B) IL-6; (C) IL-1 $\beta$; (D) TNF- $\alpha$; and $(\mathrm{E}) \mathrm{KC}$ ] response relative to the infection status represented by the number of CFU. The data are given as single observations and mean \pm S.E.M (saline $n=7, E$. coli + saline $n=20$, saline + cangrelor $n=7$, E. coli + cangrelor $(8.6 \mu \mathrm{g} / \mathrm{h}) n=10$. 
These data could suggest that there might be an additional beneficial effect by combining $\mathrm{P}_{2} \mathrm{Y}_{1}$ and $\mathrm{P} \mathrm{Y}_{12}$ receptor inhibition during the induced sepsis. Thus, we tested whether combined infusion of MRS2500 $(25.9 \mu \mathrm{g} / \mathrm{h})$ and cangrelor $(8.6 \mu \mathrm{g} / \mathrm{h})$ would give a more advantageous outcome. Unfortunately, this combination proved to be quite the opposite. The animals infused with the combination died very quickly (within an hour) with extreme bleeding tendency and a marked potentiation of the septic symptoms (data not shown).

\section{Discussion}

Sepsis constitutes the host reaction to a circulating infectious agent that potentially leads to life-threatening overstimulation of the immune system and a concomitant hypercoagulable state with a massive micro-thrombus formation and subsequent reduction of the microcirculation. Urinary tract infections are frequently the primary infection-site in patients with sepsis [3], and, thus, E. coli are found in around $30-40 \%$ of blood cultures from patients with suspected sepsis [43]. The E. coli that cause severe infection regularly produce a variety of virulence factors, of which HlyA is constantly found in clinical isolates [10]. As a virulence factor, HlyA is known to increase the risk of developing sepsis in response to a peripheral infection [44-47]. We were, however, surprised to find that this effect not only increased the invasion of bacteria to the bloodstream from peripheral infectious sites but also markedly accelerated all the septic symptoms once the bacteria was present in the blood [11]. We tested this by means of a non-HlyA-expressing E. coli strain K12, transfected with a plasmid coding for the entire hlya operon or with the same plasmid with loss of function deletion (201-2173 bp) in hlya [11]. Mice exposed to the HlyA-producing strain died early with massively increased proinflammatory cytokines, intravascular haemolysis, haemoglobinuria, thrombocytopenia and intravascular coagulation, whereas the mice exposed to an equal number of non-HlyA-producing K12 survived the full observation period with little or no changes in the sepsis parameters [11]. Since the biological effect of HlyA to a high extend is secondary to ATP release and P2 receptor activation [12,14,16,17], we were interested in whether interfering with thrombocyte activation would improve the outcome of sepsis with HlyA-producing E. coli.

The included in vitro data show that thrombocyte activation by pore-forming bacterial toxins requires $\mathrm{P} 2 \mathrm{Y}$ receptor activation, with $\mathrm{P}_{2} \mathrm{Y}_{1}$ as the predominant receptor mediating the activation. Pore-forming bacterial toxins have previously been shown to activate thrombocytes [48], and, with our previous data regarding the concomitant non-lytic ATP release, it is not exceedingly surprising. Nevertheless, these data, first of all, underscore that the biological effect of pore-forming toxins takes the flavour of the P2 receptor expression of the given target cell or tissue. Moreover, the data suggest that the erythrocytes are the main source of ATP in response to bacterial toxins because the thrombocyte activation by the toxins was much more efficient in whole blood compared to platelet enriched plasma. HlyA can, in principle, insert into any biological membrane, and, thus, any blood cell could be the source of ATP. However, the insertion of HlyA is a stochastic event, and therefore, by chance, HlyA is more likely to encounter an erythrocyte. Interestingly, the data also suggest that $\mathrm{P}_{2} \mathrm{Y}_{1}$ receptor inhibition was more efficient in preventing thrombocyte activation. One explanation could be the difference in the preferred agonist profile of the two receptors. Where ADP is the prime agonist for the $\mathrm{P} 2 \mathrm{Y}_{12}$ receptor, both ATP and ADP work as agonists for the $\mathrm{P}_{2} \mathrm{Y}_{1}$ receptor $[31,32]$. Since an ADP-dependent $\mathrm{P} 2$ receptor activation in the case of bacterial toxins would be secondary to degradation of ATP, it is likely that a receptor directly activated by the released ATP would take precedence in the following response.

Interestingly, in our sepsis model, continuous infusion of a $\mathrm{P}^{2} \mathrm{Y}_{1}$ receptor antagonist markedly increased the survival of the mice. Our model is proven to be exceedingly reliable for monitoring the development of septic symptoms in response to bacteraemia. Urosepsis is not easily modelled since mice do not readily develop sepsis after installation of bacteria in the urinary bladder. Therefore, our group has established a model that mimics a fast-developing urosepsis, as it may be seen after instrumentation of the urinary tract [11,36], to examine the effect of P2 receptors upon HlyA-induced 
ATP release for the septic response. P2 receptor activation has a substantial impact on the course of sepsis, and generally, for all $\mathrm{P} 2$ receptors tested so far, lack of or inhibition accelerates the septic

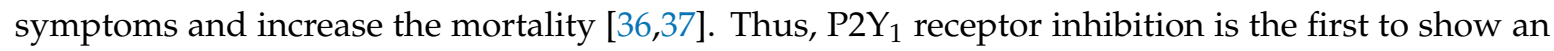
increased survival of E. coli-induced sepsis, and, therefore, the effect of MRS2500 on survival is likely to result exclusively from $\mathrm{P}_{2} \mathrm{Y}_{1}$ receptor inhibition. However, we cannot know which cell type is explicitly responsible for the positive effect on survival. We know that MRS2500 does not affect the HlyA induced haemolysis [12], and, thus, the effect of MRS2500 is not an indirect effect on the erythrocytes.

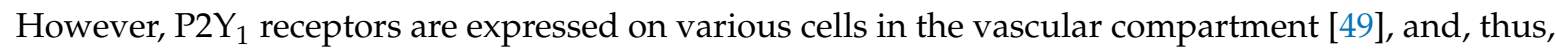
the increased survival could, in principle, result from effects on the endothelial cells or other immune cells. The expression profile for $\mathrm{P}_{2} \mathrm{Y}_{12}$ is (for review, see [50]), however, much more restrictive and is primarily confined to the thrombocytes. Therefore, it is interesting to observe that cangrelor tendentially improve the survival of sepsis even though this is not statistically significant. This indirectly supports that the effect of MRS2500 on survival may be mediated through interference with thrombocyte activation. Notably, at higher doses of cangrelor, this marginal effect is lost, which likely reflects off-target effects on other P2 receptors. In terms of the disappointing effect of cangrelor on the survival, our data here support previous studies on intravascular coagulation activated by lipopolysaccharide (LPS) in humans [51]. This study is a randomised, double-blinded, placebo-controlled study, which could not find any effect of $\mathrm{P}_{2} \mathrm{Y}_{12}$ receptor inhibition on LPS-induced intravascular coagulation.

The substantiated protocol to precisely detect human thrombocyte activation is not immediately adaptable to mice. However, if one allows the notion that the acute E. coli-induced reduction in circulating thrombocytes may partially reflect intravascular thrombocyte activation, the in vivo data do support that $\mathrm{P}_{2} \mathrm{Y}_{1}$ receptor antagonist has an effect on the thrombocytes during bacteraemia. Thus, our data confirm that intravenous injection of $E$. coli produces an early and substantial decrease in the thrombocyte count [11,36]. However, in the presence of the $\mathrm{P}_{2} \mathrm{Y}_{1}$ receptor antagonist, this response is much more variable and no longer statistically significant. This is consistent with the $\mathrm{P} 2 \mathrm{Y}_{1}$ receptor not being the only thrombocyte receptor activated by HlyA and subsequent ATP release. However, the data do underscore thrombocytes as one of the critical targets for a $\mathrm{P}_{2} \mathrm{Y}_{1}$ receptor antagonist in the bloodstream.

Notably, the reduced thrombocyte response to $\mathrm{P}_{2} \mathrm{Y}_{1}$ is not mirrored by a reduction in intravascular coagulation, which could potentially indicate that the decrease in thrombocyte numbers may not only be an effect of intravascular coagulation and microthrombus formation. Notably, injection of LPS is in itself sufficient to reduce the number of circulating thrombocytes, similar to what is observed during sepsis [52]. Interestingly, this LPS-induced reduction in circulating thrombocytes is also prevented by a $\mathrm{P} \mathrm{Y}_{1}$ receptor antagonist, whereas this is not the case for either $\mathrm{P} 2 \mathrm{X}_{1}$ or $\mathrm{P} 2 \mathrm{Y}_{12}$ receptor antagonists [52]. The authors find that the drop in circulating thrombocytes after LPS-exposure primarily results from thrombocyte translocation to the periphery tissues like the lung [52]. However, it must be noted that, in our model of urosepsis, the reduction in thrombocytes is not induced by LPS because the K12 strain with a deletion in hlya did not affect the number of circulating thrombocytes [11]. As mentioned, HlyA is known to trigger non-lytic ATP release from cells directly through the formed pore [17] and thus provides a direct link to the P2 $Y_{1}$ receptor activation. In the case of LPS, the link to P2Y receptor activation is not that straightforward but presumably involves Toll-Like Receptor 4 (TLR-4)-activation [53] and subsequent thrombolytic release of dense granules and thus ADP. Regardless, there is substantial evidence for $\mathrm{P}_{2} \mathrm{Y}_{1}$ receptor activation being central for the reduction in circulating thrombocytes as observed during sepsis. It has previously been speculated that combined inhibition of $\mathrm{P}_{2} \mathrm{Y}_{12}$ and $\mathrm{P}_{2} \mathrm{Y}_{1}$ receptor may show a benefit in some clinical situations compared to inhibition of either of the receptors alone [54]. We did, however, test the combined effect of inhibition of both receptor subtypes and found that the combination had a detrimental effect and accelerated the time of death upon intravenous exposure to uropathogenic E. coli.

Remarkably, inhibition of thrombocyte P2 receptors during sepsis seems to slightly dampen the cytokine response induced by the bacteria and their virulence factors. In the case of $\mathrm{P}_{2} \mathrm{Y}_{1}$, this was 
first obvious when the level of proinflammatory cytokines was evaluated relative to the number of circulating bacteria. This is a relevant measure because HlyA has been shown to markedly accelerate the cytokine production in this sepsis model [11] and because HlyA is only produced by live bacteria. In the case of $\mathrm{P}_{2} \mathrm{Y}_{12}$, the pattern was similar, with a less aggressive rise in the proinflammatory cytokines during sepsis. This is potentially important because mice lacking the P2X1 receptor, also show a very dampened cytokine response compared to control [37]. These findings support the notion that thrombocytes participate in the early immunological response to agents in the circulation [55]. This has been suggested to result from thrombocytes participating in the recruitment of neutrophils [56] and in the activation of neutrophils to release neutrophil extracellular traps (NETs) [57]. In Gram-negative sepsis with E. coli, NETs are induced by activation of TLR-4 on thrombocytes, that subsequently activates neutrophils via CD11a [58]. Generation of NETs is beneficial during sepsis because it can capture bacteria in the bloodstream, and thereby reduce the number of circulating bacteria [59]. This may potentially explain why we can detect a marginally, but statistically significant, increase in the number of circulating bacteria during infusion with MRS2500.

However, the dampening of the cytokine response may very well be closely associated with the increased survival observed after infusion with P2Y $_{1}$ receptor antagonist. The exceedingly high plasma levels of proinflammatory cytokines have previously been termed the cytokine storm and are known as a hallmark of severe sepsis and septic shock [42]. This auto-amplification of the immunological response is associated with a poorer outcome, but, unfortunately, attempts to dampen the response have failed in clinical trials [42]. Our sepsis model nicely reproduces elements of the cytokine storm, with exceedingly high plasma levels of proinflammatory cytokines, and, in our model, we too observed that high cytokine-levels are associated with poorer outcome [36]. If indeed the proinflammatory cytokine propels the pathogenesis during septic shock, then $\mathrm{P}_{2} \mathrm{Y}_{1}$ receptor inhibition might dampen the escalation. However, if thrombocytes were an easy early target to dampen the immune response and improve the survival of sepsis, one would potentially have expected larger responses. The question is if interference with thrombocyte function will prove to be an effective target in the treatment of sepsis, particularly because of the detrimental bleeding complications observed when targeting $\mathrm{P}_{2} \mathrm{Y}_{1}$ and $\mathrm{P}_{2} \mathrm{Y}_{12}$ in combination. Our safest bet with regard to supportive therapy would be to work on a strong, selective $\mathrm{P}_{2} \mathrm{Y}_{1}$ receptor antagonist. This may well prove to safeguard and keep the thrombocytes in circulation and simultaneously restrain cytokine auto-amplification induced by the bacteraemia.

\section{Materials and Methods}

\subsection{Animals}

Experiments were performed on male Balb/cJ mice from Janvier Labs (Saint-Berthevin, France). All animals were kept at the Department of Biomedicine, Aarhus University, Denmark, and experiments were approved by the Danish ethic committee for animal research "Dyreforsøgstilsynet" (2014-15-0201-00316).

\subsection{Bacteria}

The E. coli strain used for the experiments was kindly provided by Professor Rodney Welch (University of Wisconsin, Madison, WI, USA). The E. coli strain WAM1824 was constructed in the K12 background strain (WAM1808) [60]; a strain that does not produce HlyA and without any other virulence factors. For the HlyA-producing WAM1824 variant, the WAM1808 strain was transfected with the plasmid pWAM582, which contains the entire HlyA operon and a chloramphenicol resistance gene for selection.

WAM1824 was grown on blood agar plates supplemented with chloramphenicol $\left(20 \mu \mathrm{g} \mathrm{mL}^{-1}\right)$ and kept at $4^{\circ} \mathrm{C}$ for up to one month. Before each experiment, an overnight culture was produced by transferring one colony to $4 \mathrm{~mL}$ Lysogeny-Broth (LB)-medium containing chloramphenicol $\left(20 \mu \mathrm{g} \mathrm{mL} \mathrm{m}^{-1}\right)$ for selection. This preparation incubated overnight at $37^{\circ} \mathrm{C}$ and $250 \mathrm{rpm}$. The overnight culture $(3 \mathrm{~mL})$ was centrifuged at $1162 \times g$ for $10 \mathrm{~min}$, followed by a wash in saline $(0.9 \%)$, and centrifuged $5 \mathrm{~min}$ at 
$1162 \times g$. The bacterial pellet was re-suspended in sterile saline $(0.9 \%)$, and bacteria were counted on flow cytometry (BD Accuri 6, BD Biosciences, Franklin Lake, NJ, USA).

\subsection{Induction of Sepsis in Mice}

Male Balb/cJ mice (8-10 weeks, $24.6 \pm 0.2 \mathrm{~g}$ ) were anaesthetised by subcutaneous injection of ketamine $(100 \mathrm{mg} / \mathrm{kg})$ and xylazine $(10 \mathrm{mg} / \mathrm{kg})$ and placed on a $38^{\circ} \mathrm{C}$ heating plate. The mice were kept under anaesthesia for the duration of the experiment. The amount of anaesthesia was adjusted to the individual need, monitored by response to stimulation of whiskers and extremities. The mice were injected through the tail vein with $150 \mu \mathrm{L}$ of either $30 \times 10^{6} \mathrm{E}$. coli in solution with P2Y receptor antagonist and chloramphenicol $(33 \mu \mathrm{g})$ or $30 \times 10^{6} \mathrm{E}$. coli in saline solution with chloramphenicol $(33 \mu \mathrm{g})$. Injections were carried out with a needle $(27 \mathrm{G})$ attached to a syringe via fine tubing. The mice received a bolus injection with either the $\mathrm{P}_{2} \mathrm{Y}_{1}$ antagonist MRS2500 $(0.366 \mu \mathrm{g} / \mathrm{g})$ or the $\mathrm{P}_{2} \mathrm{Y}_{12}$ antagonist cangrelor (either $0.06 \mu \mathrm{g} / \mathrm{g}$ or $0.6 \mu \mathrm{g} / \mathrm{g}$ ) and after that continuous infusion with MRS2500 $(25.9 \mu \mathrm{g} / \mathrm{h}$ ), cangrelor $(8.6 \mu \mathrm{g} / \mathrm{h}$ or $86.4 \mu \mathrm{g} / \mathrm{h})$ or sterile saline $(66 \mu \mathrm{L} / \mathrm{h})$ throughout the experiment. For survival data, the mice were observed for up to $6 \mathrm{~h}$ and the onset of haemoglobinuria and time of death noted. For thrombocyte count, cytokines, TAT-complexes, haemolysis and blood culture, the mice were terminated after $2.5 \mathrm{~h}$, and a blood sample was drawn from the inferior vena cava with a citrate-containing syringe.

\subsection{Bacterial Load in Septic Mice}

A fixed volume of $5 \mu \mathrm{L}$ whole blood was diluted in $45 \mu \mathrm{L}$ sterile saline and streaked on an agar plate. The agar plate was incubated overnight, and the number of colony-forming units (CFU) was counted.

\subsection{Thrombocyte Count in Septic Mice}

Whole blood $(5 \mu \mathrm{L}$ ) was incubated for 15 min with $2 \mu \mathrm{L}$ CD42d antibody (BD Biosciences, Franklin Lake, NJ, USA) and $60 \mu \mathrm{L}$ PBS. Secondary fluorescein isothiocyanate (FITC)-conjugated antibody ( $2 \mu \mathrm{L}$, $\mathrm{BD}$ Bioscience) was added and incubated another $15 \mathrm{~min}$ in the dark; $20 \mu \mathrm{L}$ sample was transferred to $1.5 \mathrm{~mL}$ formaldehyde $(0.02 \%)$, and CD42-d-FITC positive cells (thrombocytes) were counted on flow cytometer (BD Accuri 6, Franklin Lake, NJ, USA).

\subsection{Measurement of Haemolysis}

Blood samples were centrifuged immediately after collection for $10 \mathrm{~min}$ at $1162 \times g$, and plasma was diluted 1:8 with saline before measurement of the absorbance at $410 \mathrm{~nm}$ on a spectrophotometer (Ultraspec III, LKB Biochom). The remaining plasma was stored at $-20^{\circ} \mathrm{C}$ for later analysis of cytokines and TAT complexes.

\subsection{Thrombin-Antithrombin (TAT) Complex}

TAT was measured in plasma samples using TAT Complexes Mouse Elisa Kit from Abcam (Cambridge, UK). Measurements were done according to manufactures instructions. Plasma was stored for up to 6 months at $-20^{\circ} \mathrm{C}$ prior to TAT measurements.

\subsection{Measurement of IL-6, IL-1 $\beta, T N F-\alpha$ and KC}

Plasma for cytokine measurements was isolated from a blood sample centrifuged for $10 \mathrm{~min}$ at $1162 \times g$. Plasma samples were kept at $-20^{\circ} \mathrm{C}$ for up to 6 months for analysis. Levels of IL-6, IL-1 $\beta$, TNF- $\alpha$ and keratinocyte chemoattractant (KC, murine equivalent to human IL-8) were measured by flow cytometry (BD Accuri 6, Franklin Lake, NJ, USA) with a cytometric bead array flex set from BD Biosciences according to the manufacturer's instruction. 


\subsection{Measurement of In Vitro Activation of Human Thrombocytes}

Blood samples were obtained from healthy volunteers with a 21-gauge needle into a $4 \mathrm{~mL}$ citrated tubes (3.2\%) after discarding the first $4 \mathrm{~mL}$ whole blood extracted. All human donors gave their written content, and the study was approved by the Danish Scientific Ethics Committee (M201100217). Platelet-rich plasma was obtained by centrifugation of whole blood at $200 \times g$ for 15 min at room temperature. Samples for both whole blood and PRP analysis were left untouched for one hour to equilibrate. Activation of thrombocytes was determined by a method previously described by Rubak et al. [39]. In short, $5 \mu \mathrm{L}$ of each antibody specific for the various thrombocyte activation markers CD42b-PE (AH diagnostics, Tilst, Denmark), CD63-PCy7 (BD Bioscience, San Jose, CA, USA), CD62P-APC (P-selectin, eBioscience, San Diego, CA, USA) and anti-fibrinogen-FITC (Diapensia HB, Linköping, Sweden) were pooled in tubes with a HEPES buffered salt solution (HBS, $30 \mu \mathrm{L})$ along with $5 \mu \mathrm{L}$ activating solution and/or $5 \mu \mathrm{L}$ P2Y-receptor antagonist. Five microlitres whole blood or PRP were added to the antibody pool, and the mixture was incubated for $10 \mathrm{~min}$ at room temperature in the dark. The samples were fixed with $0.02 \%$ formaldehyde before analysis on Navios flow cytometry (Beckman Coulter, Miami, Florida). As thrombocyte activator we used ADP (140 $\mu$ M, Sigma-Aldrich, Søborg Denmark), thrombocyte activating peptide (TRAP, $371 \mu \mathrm{M}$, JPT Peptide Technologies, Berlin, Germany), $\alpha$-toxin from S. aureus (Sigma-Aldrich, Søborg Denmark) and leukotoxin (LtxA) from A. actinomycetemcomitans (purified as previously described [61]), whereas the thrombocyte P2 receptors were inhibited by the $\mathrm{P}_{2} \mathrm{Y}_{1}$ receptor antagonist MRS2500 (Tocris, Bristol, UK) and/or the P2 $\mathrm{Y}_{12}$ receptor antagonist PSB0739 (Tocris, Bristol, UK). The concentration of $\alpha$-toxin and LtxA added was adjusted to cause approximately $25 \%$ activation of the thrombocytes. Negative controls were conducted by exchanging the agonist and receptor antagonist with an EDTA-HEPES buffer (6 mM, Sigma-Aldrich, Søborg, Denmark), whereas a sample with pure HEPES buffer was used as a measure of thrombocyte pre-activation.

\subsection{Statistics}

Statistical analyses were performed using GraphPad Prism. The data were tested for normal distribution by the Kolmogorov-Smirnov test. The in vitro data on thrombocyte activation were analysed by one-way ANOVA (Kruskal-Wallis with Dunn's post-test). Survival and studies of haemoglobinuria were analysed by Kaplan-Meier plots. Normally distributed data from the in vivo experiments were analysed with unpaired $t$-test between sepsis groups treated with either saline or MRS2500/Cangrelor. Data that were not normally distributed were analysed with Mann-Whitney test. Data from thrombocyte counts and TAT complexes were analysed with two-way ANOVA. All data are presented as mean \pm standard error of the mean, and the data were considered statistically significantly different when the $p$-value was less than 0.05 .

Author Contributions: Conceptualisation, H.P.; Data curation, M.G.C., N.J. and M.S.; Formal analysis, M.G.C., N.J. and A.D.M.H.; Funding acquisition, H.P.; Investigation, M.G.C., N.J., M.S. and H.P.; Methodology, H.A.P.; Project administration, H.P.; Supervision, P.R., A.D.M.H. and H.P.; Validation, P.R. and A.-M.H.; and Writing-original draft, M.G.C., N.J. and H.P. All authors have read and agreed to the published version of the manuscript.

Funding: This research was funded by Det Frie Forskningsråd, grant number DFF-1331-00203A.

Acknowledgments: We would like to thank Professor Rodney Welch (University of Wisconsin, Madison, WI, USA) for generously supplying the E. coli strains WAM1824. We would like to thank Helle Jakobsen for skilled technical support. The study was funded by the Independent Research Fund, Denmark (Danmarks Frie Forskningsfond): DFF-1331-00203A.

Conflicts of Interest: The authors declare no conflict of interest. 


\section{References}

1. Kennedy, J.L.; Haberling, D.L.; Huang, C.C.; Lessa, F.C.; Lucero, D.E.; Daskalakis, D.C.; Vora, N.M. Infectious Disease Hospitalizations: United States, 2001 to 2014. Chest 2019, 156, 255-268. [CrossRef]

2. Nicolle, L.E. Urinary Tract Infection. Urinary tract infection. Crit. Care Clin. 2013, 29, 699-715. [CrossRef] [PubMed]

3. Porat, A.; Kesler, S. Urosepsis; StatPearls Publishing: Treasure Island, FL, USA, 2018.

4. Flores-Mireles, A.L.; Walker, J.N.; Caparon, M.; Hultgren, S.J. Urinary tract infections: Epidemiology, mechanisms of infection and treatment options. Nat. Rev. Genet. 2015, 13, 269-284. [CrossRef] [PubMed]

5. Johnson, J.R. Virulence factors in Escherichia coli urinary tract infection. Clin. Microbiol. Rev. 1991, 4, 80-128. [CrossRef] [PubMed]

6. Connell, I.; Agace, W.; Klemm, P.; Schembri, M.A.; Marild, S.; Svanborg, C. Type 1 fimbrial expression enhances Escherichia coli virulence for the urinary tract. Proc. Natl. Acad. Sci. USA 1996, 93, 9827-9832. [CrossRef]

7. Svanborg, C. Urinary Tract Infections in Children: Microbial Virulence Versus Host Susceptibility. Retin. Degener. Dis. 2012, 764, 205-210. [CrossRef]

8. Wullt, B.; Bergsten, G.; Connell, H.; Röllano, P.; Gebretsadik, N.; Hull, R.; Svanborg, C. P fimbriae enhance the early establishment of Escherichia coli in the human urinary tract. Mol. Microbiol. 2000, 38, 456-464. [CrossRef]

9. Johnson, J.R.; Stell, A.L. Extended Virulence Genotypes ofEscherichia coliStrains from Patients with Urosepsis in Relation to Phylogeny and Host Compromise. J. Infect. Dis. 2000, 181, 261-272. [CrossRef]

10. Cavalieri, S.J.; Bohach, G.A.; Snyder, I.S. Escherichia coli $\alpha$-hemolysin: Characteristics and probable role in pathogenicity. Microbiol. Rev. 1984, 48, 326-343. [CrossRef]

11. Johnsen, N.; Hamilton, A.D.; Greve, A.S.; Christensen, M.G.; Therkildsen, J.R.; Wehmöller, J.; Skals, M.; Praetorius, H.A. $\alpha$-Haemolysin production, as a single factor, causes fulminant sepsis in a model of Escherichia coli-induced bacteraemia. Cell. Microbiol. 2019, 21, e13017. [CrossRef]

12. Skals, M.G.; Jorgensen, N.R.; Leipziger, J.; Praetorius, H.A. $\alpha$-hemolysin from Escherichia coli uses endogenous amplification through P2X receptor activation to induce hemolysis. Proc. Natl. Acad. Sci. USA 2009, 106, 4030-4035. [CrossRef] [PubMed]

13. Christensen, M.G.; Fagerberg, S.K.; de Bruijn, P.I.; Bjaelde, R.G.; Jakobsen, H.; Leipziger, J.; Skals, M.; Praetorius, H.A. $\left[\mathrm{Ca}^{2+}\right]_{\mathrm{i}}$ oscillations and IL-6 release induced by $\alpha$-hemolysin from Escherichia coli require P2 receptor activation in renal epithelia. J. Biol. Chem. 2015, 290, 14776-14784. [CrossRef] [PubMed]

14. Larsen, C.K.; Skals, M.; Wang, T.; Cheema, M.U.; Leipziger, J.; Praetorius, H.A. Python Erythrocytes Are Resistant to $\alpha$-Hemolysin from Escherichia coli. J. Membr. Biol. 2011, 244, 131-140. [CrossRef] [PubMed]

15. Skals, M.; Jensen, U.B.; Ousingsawat, J.; Kunzelmann, K.; Leipziger, J.; Praetorius, H.A. Escherichia coli $\alpha$-hemolysin triggers shrinkage of erythrocytes via KCa3.1 and TMEM16A channels with subsequent phosphatidylserine exposure. J. Biol. Chem. 2010, 285, 15557-15565. [CrossRef] [PubMed]

16. Fagerberg, S.K.; Skals, M.; Leipziger, J.; Praetorius, H.A. P2X Receptor-Dependent Erythrocyte Damage by $\alpha$-Hemolysin from Escherichia coli Triggers Phagocytosis by THP-1 Cells. Toxins 2013, 5, 472-487. [CrossRef] [PubMed]

17. Skals, M.; Bjaelde, R.G.; Reinholdt, J.; Poulsen, K.; Vad, B.S.; Otzen, D.; Leipziger, J.; Praetorius, H.A. Bacterial RTX Toxins Allow Acute ATP Release from Human Erythrocytes Directly through the Toxin Pore. J. Biol. Chem. 2014, 289, 19098-19109. [CrossRef]

18. Skals, M.; Praetorius, H.A. Mechanisms of cytolysin-induced cell damage-a role for auto- and paracrine signalling. Acta Physiol. 2013, 209, 95-113. [CrossRef]

19. Land, W.G.; Agostinis, P.; Gasser, S.; Garg, A.D.; Linkermann, A. DAMP-Induced Allograft and Tumor Rejection: The Circle Is Closing. Arab. Archaeol. Epigr. 2016, 16, 3322-3337. [CrossRef]

20. Munksgaard, P.S.; Vorup-Jensen, T.; Reinholdt, J.; Söderström, C.M.; Poulsen, K.; Leipziger, J.; Praetorius, H.A.; Skals, M. Leukotoxin fromAggregatibacter actinomycetemcomitanscauses shrinkage and P2X receptor-dependent lysis of human erythrocytes. Cell. Microbiol. 2012, 14, 1904-1920. [CrossRef]

21. Fagerberg, S.K.; Jakobsen, M.R.; Skals, M.; Praetorius, H.A. Inhibition of P2X receptors protects human monocytes against damage by leukotoxin from Aggregatibacter actinomycetemcomitans and $\alpha$-hemolysin from Escherichia coli. Infect. Immun. 2016, 84, 3114-3130. [CrossRef] 
22. Skals, M.; Leipziger, J.; Praetorius, H.A. Haemolysis induced by $\alpha$-toxin from Staphylococcus aureus requires P2X receptor activation. Pflug. Arch. 2011, 462, 669-679. [CrossRef] [PubMed]

23. Masin, J.; Fiser, R.; Linhartova, I.; Osicka, R.; Bumba, L.; Hewlett, E.L.; Benz, R.; Sebo, P. Differences in Purinergic Amplification of Osmotic Cell Lysis by the Pore-Forming RTX Toxins Bordetella pertussis CyaA and Actinobacillus pleuropneumoniae ApxIA: The Role of Pore Size. Infect. Immun. 2013, 81, 4571-4582. [CrossRef] [PubMed]

24. Nagahama, M.; Seike, S.; Shirai, H.; Takagishi, T.; Kobayashi, K.; Takehara, M.; Sakurai, J. Role of P2X7 receptor in Clostridium perfringens beta-toxin-mediated cellular injury. Biochim. Biophys. Acta 2015, 1850, 2159-2167. [CrossRef] [PubMed]

25. Hejl, J.L.; Skals, M.; Leipziger, J.; Praetorius, H.A. P2X receptor stimulation amplifies complement-induced haemolysis. Pflügers Arch.-Eur. J. Physiol. 2012, 465, 529-541. [CrossRef] [PubMed]

26. Brogly, N.; Devos, P.; Boussekey, N.; Georges, H.; Chiche, A.; Leroy, O. Impact of thrombocytopenia on outcome of patients admitted to ICU for severe community-acquired pneumonia. J. Infect. 2007, 55, 136-140. [CrossRef] [PubMed]

27. Sharma, B.; Sharma, M.; Majumder, M.; Steier, W.; Sangal, A.; Kalawar, M. Thrombocytopenia in Septic Shock Patients-A Prospective Observational Study of Incidence, Risk Factors and Correlation with Clinical Outcome. Anaesth. Intensive Care 2007, 35, 874-880. [CrossRef] [PubMed]

28. Li, Y.; Ryan, J.; Xu, F.; Vostal, J.G. Macrophage Depletion Mitigates Platelet Aggregate Formation in Splenic Marginal Zone and Alleviates LPS-Associated Thrombocytopenia in Rats. Front. Med. 2019, 6, 300. [CrossRef]

29. Chang, J.C. Sepsis and septic shock: Endothelial molecular pathogenesis associated with vascular microthrombotic disease. Thromb. J. 2019, 17, 10. [CrossRef]

30. Gachet, C.; Hechler, B. Platelet Purinergic Receptors in Thrombosis and Inflammation. Hämostaseologie 2020, 40, 145-152. [CrossRef]

31. Simon, J.; Webb, T.E.; King, B.F.; Burnstock, G.; Barnard, E.A. Characterisation of a recombinant P2Y purinoceptor. Eur. J. Pharmacol. Mol. Pharmacol. 1995, 291, 281-289. [CrossRef]

32. Boyer, J.L.; Romero-Avila, T.; Schachter, J.B.; Harden, T.K. Identification of competitive antagonists of the P2Y1 receptor. Mol. Pharmacol. 1996, 50, 1323-1329. [PubMed]

33. Daniel, J.L.; Dangelmaier, C.; Jin, J.; Ashby, B.; Smith, J.B.; Kunapuli, S.P. Molecular basis for ADP-induced platelet activation. I. Evidence for three distinct ADP receptors on human platelets. J. Biol. Chem. 1998, 273, 2024-2029. [CrossRef] [PubMed]

34. Jin, J.; Daniel, J.L.; Kunapuli, S.P. Molecular basis for ADP-induced platelet activation. II. The P2Y1 receptor mediates ADP-induced intracellular calcium mobilization and shape change in platelets. J. Biol. Chem. 1998, 273, 2030-2034. [CrossRef] [PubMed]

35. Jarvis, G.E.; Humphries, R.G.; Robertson, M.J.; Leff, P. ADP can induce aggregation of human platelets via both P2Y1 and P2T receptors. Br. J. Pharmacol. 2000, 129, 275-282. [CrossRef] [PubMed]

36. Greve, A.S.; Skals, M.; Fagerberg, S.K.; Tonnus, W.; Ellermann-Eriksen, S.; Evans, R.J.; Linkermann, A.; Praetorius, H.A. P2X1, P2X4, and P2X7 Receptor Knock Out Mice Expose Differential Outcome of Sepsis Induced by $\alpha$-Haemolysin Producing Escherichia coli. Front. Cell Infect. Microbiol. 2017, 7, 113. [CrossRef]

37. Skals, M.; Greve, A.S.; Fagerberg, S.K.; Johnsen, N.; Christensen, M.G.; Praetorius, H.A. P2X1 receptor blockers reduce the number of circulating thrombocytes and the overall survival of urosepsis with $\alpha$-haemolysin-producing Escherichia coli. Purinergic Signal. 2019, 15, 265-276. [CrossRef]

38. Arvand, M.; Bhakdi, S.; Dahlback, B.; Preissner, K.T. Staphylococcus aureus $\alpha$-toxin attack on human platelets promotes assembly of the prothrombinase complex. J. Biol. Chem. 1990, 265, 14377-14381.

39. Rubak, P.; Nissen, P.H.; Kristensen, S.D.; Hvas, A.-M. Investigation of platelet function and platelet disorders using flow cytometry. Platelets 2015, 27, 66-74. [CrossRef]

40. Assinger, A.; Schrottmaier, W.C.; Salzmann, M.; Rayes, J. Platelets in Sepsis: An Update on Experimental Models and Clinical Data. Front. Immunol. 2019, 10, 1687. [CrossRef]

41. Aslam, R.; Speck, E.R.; Kim, M.; Crow, A.; Bang, K.W.A.; Nestel, F.P.; Ni, H.; Lazarus, A.H.; Freedman, J.; Semple, J.W. Platelet Toll-like receptor expression modulates lipopolysaccharide-induced thrombocytopenia and tumor necrosis factor- $\alpha$ production in vivo. Blood 2006, 107, 637-641. [CrossRef]

42. Chousterman, B.G.; Świrski, F.K.; Weber, G.F. Cytokine storm and sepsis disease pathogenesis. Semin. Immunopathol. 2017, 39, 517-528. [CrossRef] [PubMed] 
43. Ascuntar, J.; Mendoza, D.; Jaimes, F. Antimicrobials administration time in patients with suspected sepsis: Is faster better? An analysis by propensity score. J. Intensive Intensive Care 2020, 8, 28. [CrossRef]

44. May, A.K.; Gleason, T.G.; Sawyer, R.G.; Pruett, T.L. Contribution of Escherichia coli $\alpha$-hemolysin to bacterial virulence and to intraperitoneal alterations in peritonitis. Infect. Immun. 2000, 68, 176-183. [CrossRef] [PubMed]

45. Welch, R.A.; Dellinger, E.P.; Minshew, B.; Falkow, S. Haemolysin contributes to virulence of extra-intestinal E. coli infections. Nature 1981, 294, 665-667. [CrossRef] [PubMed]

46. Welch, R.A.; Falkow, S. Characterization of Escherichia coli hemolysins conferring quantitative differences in virulence. Infect. Immun. 1984, 43, 156-160. [CrossRef]

47. Rowe, G.E.; Pellett, S.; Welch, R.A. Analysis of toxinogenic functions associated with the RTX repeat region and monoclonal antibody D12 epitope of Escherichia coli hemolysin. Infect. Immun. 1994, 62, 579-588. [CrossRef]

48. Bhakdi, S.; Muhly, M.; Mannhardt, U.; Hugo, F.; Klapettek, K.; Mueller-Eckhardt, C.; Roka, L. Staphylococcal $\alpha$ toxin promotes blood coagulation via attack on human platelets. J. Exp. Med. 1988, 168, 527-542. [CrossRef]

49. Burnstock, G. Purinergic Signaling in the Cardiovascular System. Circ. Res. 2017, 120, 207-228. [CrossRef]

50. Von Kügelgen, I. Structure, Pharmacology and Roles in Physiology of the P2Y12 Receptor. Retin. Degener. Dis. 2017, 1051, 123-138. [CrossRef]

51. Schoergenhofer, C.; Schwameis, M.; Hobl, E.-L.; Ay, C.; Key, N.S.; Derhaschnig, U.; Jilma, B.; Spiel, A. Potent irreversible P2Y12 inhibition does not reduce LPS-induced coagulation activation in a randomized, double-blind, placebo-controlled trial. Clin. Sci. 2016, 130, 433-440. [CrossRef]

52. Amison, R.; Arnold, S.; O'Shaughnessy, B.; Cleary, S.; Ofoedu, J.; Idzko, M.; Page, C.P.; Pitchford, S.C. Lipopolysaccharide (LPS) induced pulmonary neutrophil recruitment and platelet activation is mediated via the P2Y1 and P2Y14 receptors in mice. Pulm. Pharmacol. Ther. 2017, 45, 62-68. [CrossRef] [PubMed]

53. Zhang, G.; Han, J.; Welch, E.J.; Ye, R.D.; Voyno-Yasenetskaya, T.A.; Malik, A.B.; Du, X.; Li, Z. Lipopolysaccharide stimulates platelet secretion and potentiates platelet aggregation via TLR4/MyD88 and the cGMP-dependent protein kinase pathway. J. Immunol. 2009, 182, 7997-8004. [CrossRef] [PubMed]

54. Vaduganathan, M.; Bhatt, D.L. Simultaneous platelet P2Y12 and P2Y1 ADP receptor blockade: Are two better than one? Arterioscler. Thromb. Vasc. Biol. 2016, 36, 427-428. [CrossRef] [PubMed]

55. Koupenova, M.; Clancy, L.; Corkrey, H.A.; Freedman, J.E. Circulating Platelets as Mediators of Immunity, Inflammation, and Thrombosis. Circ. Res. 2018, 122, 337-351. [CrossRef] [PubMed]

56. Amison, R.; O'Shaughnessy, B.G.; Arnold, S.; Cleary, S.J.; Nandi, M.; Pitchford, S.C.; Bragonzi, A.; Page, C.P. Platelet Depletion Impairs Host Defense to Pulmonary Infection withPseudomonas aeruginosain Mice. Am. J. Respir. Cell Mol. Biol. 2018, 58, 331-340. [CrossRef]

57. Yang, S.; Qi, H.; Kan, K.; Chen, J.; Xie, H.; Guo, X.; Zhang, L. Neutrophil Extracellular Traps Promote Hypercoagulability in Patients with Sepsis. Shock 2017, 47, 132-139. [CrossRef] [PubMed]

58. Lipinska-Gediga, M. Neutrophils, NETs, NETosis-old or new factors in sepsis and septic shock? Anaesthesiol. Intensive Ther. 2017, 49, 235-240. [CrossRef]

59. McDonald, B.; Urrutia, R.; Yipp, B.G.; Jenne, C.; Kubes, P. Intravascular Neutrophil Extracellular Traps Capture Bacteria from the Bloodstream during Sepsis. Cell Host Microbe 2012, 12, 324-333. [CrossRef]

60. Moxley, R.A.; Berberov, E.M.; Francis, D.H.; Xing, J.; Moayeri, M.; Welch, R.A.; Baker, D.R.; Barletta, R.G. Pathogenicity of an enterotoxigenic Escherichia coli $\alpha$-hemolysin (hlyA) mutant in gnotobiotic piglets. Infect. Immun. 1998, 66, 5031-5035. [CrossRef]

61. Reinholdt, J.; Poulsen, K.; Brinkmann, C.R.; Hoffmann, S.V.; Stapulionis, R.; Enghild, J.J.; Jensen, U.B.; Boesen, T.; Vorup-Jensen, T. Monodisperse and LPS-free Aggregatibacter actinomycetemcomitans leukotoxin: Interactions with human $\beta 2$ integrins and erythrocytes. Biochim. Biophys. Acta 2013, 1834, 546-558. [CrossRef]

(C) 2020 by the authors. Licensee MDPI, Basel, Switzerland. This article is an open access article distributed under the terms and conditions of the Creative Commons Attribution (CC BY) license (http://creativecommons.org/licenses/by/4.0/). 